\title{
Chemical characteristics of soil cultivated with vine and submitted to nitrogen and organic fertilization at the semiarid of the Rio Grande do Norte State, Brazil
}

\author{
Franciezer Vicente de Lima ${ }^{*}$, Vander Mendonça' ${ }^{1}$ Anderson Araújo Alves' \\ Eduardo Castro Pereira ${ }^{2}$, Gustavo Alves Pereira ${ }^{3}$, Wagner César de Farias ${ }^{1}$
}

\author{
'Universidade Federal Rural do Semi-Árido \\ 2Instituto Federal do Rio Grande do Norte \\ 3Universidade Federal do Piaui \\ *Corresponding author, e-mail: franciezer@hotmail.com
}

\begin{abstract}
A probable reason for the scarce levels of $\mathrm{N}$ in the soils of the semi-arid regions would be the low levels of organic matter in these soils. In this way, the aim of the present study was to evaluate the effects of nitrogen and organic fertilization and their interaction on chemical properties of soils cultivated with 'Isabel Precoce' vines in the semiarid oh the Rio Grande do Norte State, Brazil. The experiment was carried out at the Experimental Farm of the Federal Rural University of the Semi-arid Region, in Mossoró, RN. The soil in the area is classified as a Distrofic Red Argisol with sandy texture. The research was carried out in two cycles of grape production. The experiment was accomplish in a randomized blocks design, with six repetitions, in a $5 \times 2$ factorial scheme, corresponding to 5 doses of nitrogen fertilization $\left(0,30,60,90\right.$ and $\left.120 \mathrm{~kg} \mathrm{ha}^{-1}\right)$, in the absence and presence of organic fertilization 0 and $20 \mathrm{~m}^{3} \mathrm{ha}^{-1}$, bovine manure). Samples of the $0-20$ $\mathrm{cm}$ layer were collected for the evaluation of macro and micronutrient contents, $\mathrm{pH}$, electric condutivity, organic matter and sum of bases. The $\mathrm{N}$ and organic fertilization doses influenced the chemical atributes evaluated. The interaction between nitrogen and organic fertilizer resulted in an increase in nutrient, organic matter and sum of bases content. $\mathrm{N}$ doses were responsible for reducing $\mathrm{pH}$ levels, resulting in higher amounts of nutrients availability.
\end{abstract}

Keywords: fertility, mineralization, nutrients, organic matter

Introduction

Among the nutrients required by the cultivated plants, nitrogen $(\mathrm{N})$ is one of the most limiting to plant development (VERAS et al., 2016). In literature, it is possible to verify the $\mathrm{N}$ influence on yield and quality of vine fruits (BRUNETTO 2009; LORENSINI et al., 2014, 2015). As most of the soils of the Northeast region og Brazil present low organic matter content and since this is the most natural nutrients supplier to the soil, mainly $\mathrm{N}$, it is necessary the use of mineral sources to meet the plant needs to obtain satisfatory yields.

Due to these characteristics, the addition of organic fertilizers (animal manures) as a form of supplemental fertilization may be an alternative to increase the soil nutrient contents, in addition, it is assumed that the application of organic material on soils induces the increase of microbial activity, providing improvements in the construction and maintenance of soil fertility (SOUTO et al., 2013). This would result in savings on the use of mineral fertilizers, given the high prices currently experienced for such fertilizers. Thus, it is possible the use of organic fertilization, which most of the times are available in the rural properties of the Northeast region of Brazil (GALVÃO et al., 2008), reducing costs and making the property more sustainable and economical.

However, there are no experimental results that provide technical information 
rearding the specific crop and soil of the region. In the Northeast of Brazil, most of the researches with vines are concentrated almost exclusively in the Submedium of the São Francisco River Valley, with a need of local knowledge. The objective of this research was to investigate the effects of nitrogen and organic fertilization and its interaction on the chemical properties of the soil cultivated with 'Isabel Precoce' vines in the semiarid region of the Rio Grande do Norte State, Brazil.

\section{Materials and Methods}

The experiment was carried out at the Rafael Fernandes Experimental Farm, of the
Federal Rural University of the Semi-arid Region (UFERSA), in the municipality of Mossoró, in the western region of the Rio Grande do Norte State, whose geographical coordinates are $5^{\circ} 03^{\prime} 37$ "S of latitude and, $37^{\circ} 23^{\prime} 50^{\prime \prime} \mathrm{W}$ of longitude, with an altitude of $78 \mathrm{~m}$ and flat relief. According to Köppen's classification, the climate of the region is BSW'h 'type, tropical semiarid hot, with average annual rainfall of $695.8 \mathrm{~mm}$ and average temperature of $27.4^{\circ} \mathrm{C}$, with two well defined periods: dry (prolonged) and humid (short and irregular). The natural vegetation is the Hyperxerophilic Caatinga. In Table 1 is possible to observe the meteorological data recorded during the experiments.

Table 1. Recorded rainfall, mean temperature and relative air humidity during the period of the experiments. Mossoró-RN, Brazil, 2017.

\begin{tabular}{|c|c|c|c|}
\hline Month & $\begin{array}{l}\text { Precipitation } \\
\text { (mm) }\end{array}$ & $\begin{array}{l}\text { Mean temperature } \\
\left({ }^{\circ} \mathrm{C}\right)\end{array}$ & $\begin{array}{l}\text { Humidity } \\
\text { (\%) }\end{array}$ \\
\hline \multicolumn{4}{|c|}{2015} \\
\hline September & 0.0 & 27.9 & 57.0 \\
\hline October & 0.0 & 28.0 & 56.8 \\
\hline November & 0.0 & 28.2 & 59.6 \\
\hline December & 8.0 & 28.8 & 58.7 \\
\hline \multicolumn{4}{|c|}{2016} \\
\hline April & 51.0 & 28.6 & 63.7 \\
\hline May & 8.0 & 28.7 & 61.5 \\
\hline June & 29.0 & 28.2 & 59.8 \\
\hline July & 0.0 & 28.2 & 52.8 \\
\hline
\end{tabular}

The soil of the experimental area was classified a Typical Distrofic Red Argisol, with sandy texture (RÊGO et al., 2016). Before the installation of the experiment, soil samples of the
0-20 cm layer were collected and the physical and chemical characteristics determined (TEDESCO et al., 1995; EMBRAPA, 2009), being the results presented in Table 2.

Table 2. Chemical and physical characteristics of a typical Dystrophic Red Argisol $(0-20 \mathrm{~cm})$ with sandy texture, before the experiment implementation. Mossoró, RN, Brazil, 2017.

\begin{tabular}{|c|c|c|c|}
\hline Attribute & Value & Attribute & Value \\
\hline $\mathrm{pH}\left(\mathrm{H}_{2} \mathrm{O}\right)$ & 7.95 & $\mathrm{~V}(\%)$ & 100 \\
\hline Electrical condutivity $\left(\mu \mathrm{S} \mathrm{m}^{-1}\right)$ & 80.0 & $M(\%)$ & 0 \\
\hline Organic matter $\left(\mathrm{g} \mathrm{kg}^{-1}\right)$ & 4.07 & $\operatorname{ESP}(\%)$ & 1 \\
\hline Total $\mathrm{N}\left(\mathrm{g} \mathrm{kg}^{-1}\right)$ & 0.77 & $\mathrm{Cu}\left(\mathrm{mg} \mathrm{dm} \mathrm{dm}^{-3}\right)$ & 1.11 \\
\hline$P\left(\mathrm{mg} \mathrm{dm}^{-3}\right)$ & 39 & $\mathrm{Fe}\left(\mathrm{mg} \mathrm{dm}^{-3}\right)$ & 12.57 \\
\hline $\mathrm{K}^{+}\left(\mathrm{mg} \mathrm{dm}^{-3}\right)$ & 117 & $\mathrm{Mn}\left(\mathrm{mg} \mathrm{dm}^{-3}\right)$ & 29.75 \\
\hline $\mathrm{Na}^{+}\left(\mathrm{mg} \mathrm{dm}^{-3}\right)$ & 49 & $\operatorname{Zn}\left(\mathrm{mg} \mathrm{dm}^{-3}\right)$ & 4.0 \\
\hline $\mathrm{Ca}^{2+}\left(\mathrm{cmol}_{\mathrm{c}} \mathrm{dm}^{-3}\right)$ & 4.17 & Sand $\left(\mathrm{g} \mathrm{kg}^{-1}\right)$ & 836 \\
\hline $\mathrm{Mg}^{2+}\left(\mathrm{cmol}_{\mathrm{c}}^{\mathrm{c}} \mathrm{dm}^{-3}\right)$ & 1.05 & Silt $\left(g \mathrm{~kg}^{-1}\right)$ & 84 \\
\hline $\mathrm{Al}^{3+}\left(\mathrm{cmol}_{\mathrm{c}} \mathrm{dm}^{-3}\right)$ & 0.0 & Clay $\left(\mathrm{g} \mathrm{kg}^{-1}\right)$ & 80 \\
\hline$(\mathrm{H}+\mathrm{Al})\left(\mathrm{cmol}_{\mathrm{c}} \mathrm{dm}^{-3}\right)$ & 0.0 & Soil density $\left(\mathrm{kg} \mathrm{dm}^{-3}\right)$ & 1.54 \\
\hline $\mathrm{SB}\left(\mathrm{cmol} \mathrm{dm}^{-3}\right)$ & 5.73 & Particle density $\left(\mathrm{kg} \mathrm{dm}^{-3}\right)$ & 2.63 \\
\hline Effective CEC $\left(\mathrm{cmol}_{\mathrm{c}} \mathrm{dm}^{-3}\right)$ & 5.73 & Total porosity (\%) & 41.44 \\
\hline Soil CEC $\left(\mathrm{cmol}_{\mathrm{c}} \mathrm{dm}^{-3}\right)$ & 5.73 & & \\
\hline
\end{tabular}


The research was carried out in two cycles of vine production, being the first from September 22 to December 23, 2015, and the second from April 14 to July 20, 2016, corresponding to a total of 92 and 97 days, respectively, from pruning to harvest.

The vine variety 'Isabel Precoce' grafted on 'IAC 766' rootstock was used. At the time of the experiment, the vines were five years old, which is considered a time for the vine to express its productive potential. The plants were spaced in $3 \times 2 \mathrm{~m}$ of lines and plants, respectively $(1,667$ plants $\mathrm{ha}^{-1}$ ), conducted in a sparlier (open $\mathrm{Y}$ ) system with 3-wires and North-South orientated.

The traits for crop development were similar in both cycles. Prior to the application of the treatments, manual weeding was performed to remove the spontaneous plants in a radius of approximately $70 \mathrm{~cm}$ (considering the stem of the vine as the center of the area), while the mechanical trimmer was used between lines.

The irrigation system used was micro sprinkler with 1 hour watering and irrigation frequency on every 24 hours. The calculation of the irrigation depth was based on the reference evapotranspiration (ETo), with parameters measured through the meteorological station installed in the Experimental Farm. The water table was applied according to the cultivation coefficient of the vine for each phenological phase (BASSOI et al., 2007).

The experimental was carried out in a randomized block design with six repetitions, in a 5 $\times 2$ factorial scheme, corresponding to 5 doses of nitrogen fertilizer $\left(0,30,60,90\right.$ and $\left.120 \mathrm{~kg} \mathrm{ha}^{-1}\right)$, in the absence and presence of organic fertilization

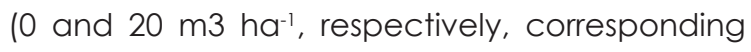
to 13.3 tonnes $\mathrm{ha}^{-1}$, dry basis). The nitrogen fertilization was carried out with urea $(45 \% \mathrm{~N})$ and the application was divided as follows: $50 \%$ in one week before pruning and the remaining $50 \%$ fractionated in four weekly applications. The source of organic fertilization was bovine manure, applied in a single dose with the first nitrogen application. A sample of the organic fertilizer was collected and sent for analysis, the chemical characteristics are described in Table 3. The mineral and organic fertilizers were applied to soil surface and imediatly after the fertilization process, the area was irrigated to reduce the $\mathrm{N}$ losses by volatilization.

Table 3. Chemical characteristics of the cattle manure used in the experiment and the proportional amount of nutrients added per plant and per hectare contained in the $20 \mathrm{~m}^{3}$ ha- $^{-1}$ of the organic fertilizer, Mossoró, RN, Brazil 2017.

\begin{tabular}{|c|c|c|c|c|c|c|c|c|c|c|}
\hline $\mathrm{N}$ & $C$ & $P$ & $\mathrm{~K}^{+}$ & $\mathrm{Na}^{+}$ & $\mathrm{Ca}^{2+}$ & $\mathrm{Mg}^{2+}$ & $\mathrm{Cu}$ & $\mathrm{Fe}$ & $M n$ & $\mathrm{Zn}$ \\
\hline & & . & $-g_{k g}^{-1}$ & & & ------- & ----- & $-----m$ & $\mathrm{~kg}^{-1}-$ & ------ \\
\hline 9.81 & 104.11 & 2.43 & 9.47 & 2.78 & 10.04 & 4.88 & 11 & 157 & 250 & 164 \\
\hline 78.5 & 832.9 & 19.44 & 75.8 & 22.24 & 80.32 & 39.04 & 0.09 & 1.26 & 2.0 & 1.31 \\
\hline 130.86 & 1.388 .8 & 32.42 & 126.33 & 37.08 & 133.93 & 65.1 & 0.15 & 2.1 & 3.33 & 2.18 \\
\hline
\end{tabular}

The current soil fertility of the experimental area was observed (Table 2) in order to verify the need of soil correction, providing optimum development conditions for all experimental units. Based on these results and following the fertilization recommendations for grapevine cultivation (IPA, 2008), a corrective fertilizer, with the exception of nitrogen, was applied, restricting the soil of the tested nutrient. Thus, $80 \mathrm{~kg} \mathrm{ha}^{-1}$ of $\mathrm{P}_{2} \mathrm{O}_{5}$ and $150 \mathrm{~kg} \mathrm{ha}^{-1}$ of $\mathrm{K}_{2} \mathrm{O}$ were applied, using simple superphosphate and potassium chloride, respectively. Phosphorus was applied in a single dose together with the first application of $\mathrm{N}$, The potassium fertilization followed the same schedule used for $\mathrm{N}$ doses.

At the end of each experimental cycle, soil samples were collected from the $0-20 \mathrm{~cm}$ layer in all experimental units, aiming to evaluate the chemical characteristics: macronutrients $(\mathrm{N}$, $\mathrm{P}, \mathrm{K}, \mathrm{Ca}$ and $\mathrm{Mg}$ ), micronutrients (Fe, $\mathrm{Mn}$ and $\mathrm{Zn})$, sodium ( $\mathrm{Na})$, hydrogenionic potential $(\mathrm{pH})$, electrical conductivity (EC), organic matter 
content (OM) and sum of bases (SB).

The $\mathrm{pH}$ and $\mathrm{EC}$ were determined in water, with the ratio 1:2.5 soil:water. Nitrogen was determined from sulfur digestion and quantified by the Kjeldahl method. $\mathrm{Ca}^{2+}$ and $\mathrm{Mg}^{2+}$ were extracted with $1 \mathrm{~mol} \mathrm{~L}^{-1}$ with $\mathrm{KCL}$ solution at the ratio 1:10 soil:solution, and determined by EDTA titration. $\mathrm{K}^{+}, \mathrm{Na}^{+}$and $\mathrm{P}$ were extracted with Mehlich 1 solution at the ratio 1:10 soil:solution. $\mathrm{K}^{+}$ and $\mathrm{Na}^{+}$were determined by flame photometry, and $\mathrm{P}$ by spectrophotometry. The organic matter content was determined by wet oxidation of the organic matter by $0.2 \mathrm{~mol} \mathrm{L^{-1 }}$ of potassium dichromate in sulfuric medium and titration with $0.1 \mathrm{~mol} \mathrm{~L}^{-1}$ with ammoniacal ferrous sulfate. The micronutrients were determined in an atomic absorption spectrometer using the Mehlich 1 extractor. With the analytical results the sum of bases (SB) was calculated, following the methodology of Embrapa (2009).

The results were submitted to variance analysis, using the T test to compare the averages to the qualitative factor (organic Fertilizer), at 5\% of probability level. For the quantitative factor $(N)$ and for interaction between the factors, regression equations were adjusted by testing the linear and quadratic models by the F test, choosing the one with less than $5 \%$ of significance, using the $R$ statistical software, Expdes.pt package.

\section{Results and discussion}

After the evaluations carried out at the end of the production cycles, the occurrence of changes in soil chemical characteristics was verified. It was observed a significant effect ( $\mathrm{p} \leq$ 0.05) of the interaction of Nitrogen (N) x Organic Fertilizer (AO) for all evaluated variables.

Regarding the total nitrogen contents of the soil, analyzing within the levels of $\mathrm{N}$ studied, it is observed that the average values of $\mathrm{N}$ concentration in the levels of organic fertilization, after the cycles of cultivation of the vine and in all $\mathrm{N}$ doses, ( $\mathrm{p} \leq 0.01$ ) were adjusted to the linear regression model, meaning that in both the presence and absence of the organic fertilizer, the average concentration of $\mathrm{N}$ in the soil increased proportionally to the increase of the applied $\mathrm{N}$ doses.

For the dose of $120 \mathrm{~kg} \mathrm{ha}^{-1}$ of $\mathrm{N}$, in the presence of organic fertilizer, the content of 1.36 and $1.35 \mathrm{~g} \mathrm{~kg}^{-1}$ of $\mathrm{N}$, in the first and second cycle, respectively, was estimated. With no organic fertilization the contents were 1.14 and $1.17 \mathrm{~g} \mathrm{~kg}^{-1}$ of $\mathrm{N}$ (Table 4). Using the organic fertilizer the total $\mathrm{N}$ concentration of the soil presented a superiority of $19.3 \%$ in the first cycle and $15.4 \%$ in the second one, proving the influence of the nitrogen on the mineralization process of the nutrients of the organic fertilizer added to the soil. Taking into consideration that the estimated $\mathrm{N}$ content in manure was approximately $131.0 \mathrm{~kg} \mathrm{ha}^{-1}$ (Table $3)$, it may have contributed to these results.

On the other hand, evaluating the levels of organic fertilizer studied, all $\mathrm{N}$ applied promoted a higher average concentration of $\mathrm{N}$ in the presence of organic fertilizer, except in the absence of $\mathrm{N}$, where the effect of organic fertilizer addition was not verified (Table 4). This is due to the immobilization of nitrogen by microbial biomass (MENEZES \& SALCEDO, 2007), which caused changes in the $\mathrm{C}$ : $\mathrm{N}$ ratio, due to the high carbon load added to the soil by the organic fertilization (1,389 $\mathrm{kg} \mathrm{ha}^{-1}$, Table 3) favoring the immobilization process.

In a simplified way, it can be explained that when the deposition of organic residues (plants or animals) on the soil surface is promoted, it results in a development of microorganisms (Silva et al., 2014b). These microorganisms are responsible for the decomposition of the organic material deposited in the soil and require nitrogen to use it as energy source in the decomposition process. If the deposited material has a high $\mathrm{C}$ : $\mathrm{N}$ ratio, which means little nitrogen to meet the needs of the microorganisms, both the nitrogen present in the organic material and the soil $\mathrm{N}$ can be incorporated by the microbial biomass, causing its immobilization (GIACOMINI et al., 2009; SILVA et al., 2014b).

The relevance of this previous fact and part of the results of the presente study has a strong connection with the activity of soil microorganisms. There are many factors influencing the nutrientes of the oganic fertilizer to be mineralized and its availability, such as the material (vegetable or animal), soil and climate conditions, chemical composition, the lignin content, the C: N ratio, as well as the nature and 
community of the decomposing microorganisms (SILVA et al., 2014b). Among these, the C: N ratio is of great importance, since the imbalance of this relation can delay the speed in which this material is decomposed, causing immobilization of the $\mathrm{N}$ present in the soil.

Table 4: Nitrogen $(N)$, phosphorus $(P)$, potassium $(K)$, calcium $(\mathrm{Ca})$ and magnesium $(\mathrm{Mg})$ concentration in the soil cultivated with vines, under the influence of nitrogen fertilization, with and without the use of organic fertilizer in two crop cycles. Mossoró, RN, Brazil 2017.

\begin{tabular}{|c|c|c|c|c|c|c|c|c|}
\hline \multirow{2}{*}{ Variable } & \multirow{2}{*}{ OF } & \multicolumn{5}{|c|}{ Nitrogen doses $\left(\mathrm{kg} \mathrm{ha}^{-1}\right)$} & \multirow{2}{*}{ Equation } & \multirow{2}{*}{$R^{2}$} \\
\hline & & 0 & 30 & 60 & 90 & 120 & & \\
\hline \multicolumn{9}{|c|}{$1^{\text {st }}$ cycle } \\
\hline \multirow{2}{*}{$\mathrm{N}$} & Without & $0.51 a$ & $0.59 \mathrm{~b}$ & $0.78 b$ & $1.04 \mathrm{~b}$ & $1.12 \mathrm{~b}$ & $y=0.4743+0.0056 x$ & $0.97^{* *}$ \\
\hline & With & $0.41 b$ & $0.81 a$ & $1.03 a$ & $1.17 a$ & $1.28 \mathrm{a}$ & $y=0.5226+0.007 x$ & $0.93^{* *}$ \\
\hline \multirow{2}{*}{$P$} & Without & $41.55 a$ & $42.90 \mathrm{~b}$ & $43.34 \mathrm{~b}$ & $42.92 b$ & $43.02 \mathrm{~b}$ & $y=41.674+0.0419 x-2.6 e^{-4} x^{2}$ & $0.88^{*}$ \\
\hline & With & $41.65 a$ & $47.22 a$ & $48.68 a$ & $49.98 a$ & $50.78 a$ & $y=42.069+0.1625 x-7.7 e^{-4} x^{2}$ & $0.97^{* *}$ \\
\hline \multirow{2}{*}{ K } & Without & $127.5 b$ & $128.9 \mathrm{~b}$ & $130.5 b$ & $131.0 \mathrm{~b}$ & $132.0 \mathrm{~b}$ & $y=127.650+0.0387 x$ & $0.97^{* *}$ \\
\hline & With & $128.8 a$ & $133.7 a$ & $138.1 \mathrm{a}$ & $143.4 a$ & $147.9 a$ & $y=128.753+0.1601 x$ & $0.99 * *$ \\
\hline \multirow{2}{*}{$\mathrm{Ca}$} & Without & $4.04 b$ & $4.09 b$ & $4.15 b$ & $4.10 \mathrm{~b}$ & $4.14 b$ & $\bar{y}=4.10 \mathrm{cmol}_{c} \mathrm{dm}^{-3}$ & $-^{2}$ \\
\hline & With & $4.16 a$ & $4.30 a$ & $4.37 a$ & $4.43 a$ & $4.43 a$ & $y=4.16+0.0051 x-2.3 e^{-5} x^{2}$ & $0.99 * *$ \\
\hline \multirow{2}{*}{$\mathrm{Mg}$} & Without & $0.99 b$ & $1.04 b$ & $1.03 b$ & $1.03 b$ & $1.02 \mathrm{~b}$ & $\bar{y}=1.02 \mathrm{cmol}_{\mathrm{c}} \mathrm{dm}^{-3}$ & -1 \\
\hline & With & $1.15 a$ & $1.27 \mathrm{a}$ & $1.37 a$ & $1.45 a$ & $1.55 \mathrm{a}$ & $y=1.1397+0.0035 x$ & $0.98^{*}$ \\
\hline \multicolumn{9}{|c|}{$2^{\text {nd }}$ cycle } \\
\hline \multirow{2}{*}{$\mathrm{N}$} & Without & $0.48 a$ & $0.59 \mathrm{~b}$ & $0.76 b$ & $1.04 \mathrm{~b}$ & $1.17 b$ & $y=0.449+0.0060 x$ & $0.98 * *$ \\
\hline & With & $0.42 \mathrm{~b}$ & $0.81 a$ & $1.02 \mathrm{a}$ & $1.17 a$ & $1.27 a$ & $y=0.531+0.0068 x$ & $0.93^{* *}$ \\
\hline \multirow{2}{*}{$P$} & Without & $41.12 b$ & $41.84 \mathrm{~b}$ & $42.60 \mathrm{~b}$ & $42.68 b$ & $42.79 b$ & $y=41.101+0.0321 x-1.5 e^{-4} x^{2}$ & $0.98^{* *}$ \\
\hline & With & $42.43 a$ & $46.52 a$ & $49.07 a$ & $50.18 a$ & $50.30 a$ & $y=42.483+0.1539 x-7.4 e^{-4} x^{2}$ & $0.99 * *$ \\
\hline \multirow{2}{*}{ K } & Without & $126.7 \mathrm{~b}$ & $128.0 \mathrm{~b}$ & $129.7 \mathrm{~b}$ & $130.1 b$ & $131.1 \mathrm{~b}$ & $y=126.826+0.0374 x$ & $0.95^{* *}$ \\
\hline & With & $129.7 a$ & $134.6 a$ & $138.8 a$ & $144.0 \mathrm{a}$ & $148.1 a$ & $y=129.865+0.1531 x$ & $0.99 * *$ \\
\hline \multirow{2}{*}{$\mathrm{Ca}$} & Without & $3.99 b$ & $4.09 b$ & $4.13 b$ & $4.12 \mathrm{~b}$ & $4.12 \mathrm{~b}$ & $\bar{y}=4.09 \mathrm{cmol}_{\mathrm{c}} \mathrm{dm}^{-3}$ & -2 \\
\hline & With & $4.19 a$ & $4.33 a$ & $4.41 \mathrm{a}$ & $4.42 \mathrm{a}$ & $4.44 \mathrm{a}$ & $y=4.196+0.0049 x-2.3 e^{-5} x^{2}$ & $0.98^{* *}$ \\
\hline \multirow{2}{*}{$\mathrm{Mg}$} & Without & $0.95 b$ & $0.96 b$ & $0.98 b$ & $0.96 b$ & $0.96 b$ & $\bar{y}=0.96 \mathrm{cmol}_{\mathrm{c}} \mathrm{dm}^{-3}$ & -1 \\
\hline & With & $1.14 \mathrm{a}$ & $1.34 \mathrm{a}$ & $1.41 \mathrm{a}$ & $1.45 a$ & $1.57 \mathrm{a}$ & $y=1.1886+0.0032 x$ & $0.93^{* *}$ \\
\hline
\end{tabular}

Thus, the $\mathrm{N}$ doses $(30,60,90$ and 120 $\mathrm{kg} \mathrm{ha}^{-1}$ ) used in this study may have promoted a better equilibrium in the $\mathrm{C}: \mathrm{N}$ ratio, leading to more satisfactory conditions for the mineralization process of nutrients present in the organic fertilizer. As a result, the availability of the nutrients may have undergone variations in the release time, whether in an accelerated or paced manner. In the studies carried out by Carneiro et al. (2013), Silva et al. (2014a) and Lorensini et al. (2014), the authors report the influence on the release of nutrients by several organic materials due to changes in the $\mathrm{C}$ : $\mathrm{N}$ ratio, as well as the influence of the addition of mineral $N$ associated with organic materials (POTRICH et al., 2014 e SILVA et al., 2016).

In general, when in the presence of organic fertilizer, the $\mathrm{N}$ doses result in higher values of phosphorus (P) concentration in the soil, except in the absence of nitrogen for the first cycle, in which, both in the absence and in the presence of the fertilizer, no influence on $P$ concentration was observed (Table 4). This can be due to the immobilization previously mentioned, since, as no nitrogen was added, the decomposition process may have been reduced and with this, it is estimated that it affected the release of the $P$ present in the organic fertilizer. Relative to the second cycle, in the presence of the organic fertilizer, $P$ was available at all levels of nitrogen applied, which may be due to the $P$ supply in the organic fertilizer (Table 3 ).

In both cycles, the $\mathrm{P}$ presented increments with quadratic adjustment to increase their contents. In the combination of doses of $\mathrm{N}$ with organic fertilizer, the highest values were 50.6 and $50.5 \mathrm{mg} \mathrm{dm}^{-3}$ of $\mathrm{P}$, estimated at the doses of 105.5 and $103.9 \mathrm{~kg} \mathrm{ha}^{-1}$ of $\mathrm{N}$. Without the organic fertilizer, the contents were 43.3 and $42.8 \mathrm{mg} \mathrm{dm}^{-3}$ of $\mathrm{P}$, estimated at the doses of 84.6 and $107.0 \mathrm{~kg} \mathrm{ha}^{-1}$ of $\mathrm{N}$ for the first and second cycle, respectively. The average 
concentrations of $\mathrm{P}$ in the presence of organic fertilizer can be explained due to the actual supply of phosphorus by manure, estimated at approximately $33 \mathrm{~kg} \mathrm{ha}^{-1}$ of $\mathrm{P}_{2} \mathrm{O}_{5}$ (Table 3 ), which corresponds to an application of $183.3 \mathrm{~kg} \mathrm{ha}^{-1}$ of single superphosphate ( $18 \%$ of $\mathrm{P}$ ).

It is important to observe that all experimental units received $\mathrm{P}_{2} \mathrm{O}_{5}(80 \mathrm{~kg}$ ha 1) as a corrective fertilizer and, possibly, the average values observed in the treatment without application of the organic fertilizer to the $\mathrm{P}$ content, were influenced by the decrease of the $\mathrm{pH}$, since, before the installation of the experiment, the soil of the area presented a pH of 7.95 (Table 2) and under these conditions, the availability of phosphorus is compromised.

According to Malavolta (1979), the pH range that allows the best $P$ availability is between 6.5 and 7.2, with progressive unavailability for values below or above this range. In this way, according to the values of the $\mathrm{pH}$ variable on Table 6 , it can be observed that, with the increase of $\mathrm{N}$ doses, a linear decrease in soil $\mathrm{pH}$ occurred, which probably favored better phosphorus availability. This dynamics verified in the reduction of $\mathrm{pH}$ and the reasons for the occurrence of such effect will be treated with more emphasis in the discussion of this specific variable.

In a study carried out by Maeda \& Bognola (2012) evaluating the influence of $\mathrm{pH}$ on the efficiency of phosphorus use, the authors concluded that at $\mathrm{pH}$ close to neutrality, the soil phosphorus availability was higher, increasing the efficiency of use.

$$
\text { Regarding the potassium }
$$

concentration in the soil within the studied doses of organic fertilizer, it was observed a higher average concentration of $K$ in the presence of organic fertilizer (Table 4). The addition of organic fertilizer was essential for the soil $K$ availability. On the other hand, evaluating the $\mathrm{N}$ doses, the average concentration of $K$ for the organic fertilizer level were both adjusted $(p \leq 0.01)$ to the linear regression model, meaning that, both in the presence and in the absence of organic fertilizer, the soil $\mathrm{K}$ concentration increased proportionally to the increase of the $\mathrm{N}$ doses applied.

At the highest $N$ dose $\left(120 \mathrm{~kg} \mathrm{ha}^{-1}\right)$, it was estimated by the regression equations the contentes of 147.9 and $148.2 \mathrm{mg} \mathrm{dm}^{-3}$ of $\mathrm{K}$ when using organic fertilizer and 132.2 and 131.3 $\mathrm{mg} \mathrm{dm}{ }^{-3}$, without the organic fertilizer, for the first and second cycle, respectively. Taking into consideration the average obtained by the sum of the values observed in each cycle, it is verified that, in the presence of the organic fertilizer, the $\mathrm{N}$ doses resulted in an increase of $12.4 \%$ when compared to the effect of the $\mathrm{N}$ doses. This linear increase in $\mathrm{K}$ levels may have been caused by the actual contribution of the organic fertilizer, which was approximately $126.0 \mathrm{~kg} \mathrm{ha}^{-1}$ (Table 3). The effect provided by the manure and other organic residues on the increase of soil $K$ levels were also reported by Jiménez Becker et al. (2010), Bustamante et al. (2011) and Clemente et al. (2012).

Regarding the observed results for $\mathrm{K}$ contents whithout $\mathrm{N}$ doses in the organic fertilizer, it can be observed that even with linear regression adjustment (Table 4), the average values observed in the absence of $\mathrm{N}$ (127.5 and $126.7 \mathrm{mg} \mathrm{dm}^{-3}$ of $\mathrm{K}$ ) in the first and second cycles are similar to the average values (132.0 and 131.1 $\mathrm{mg} \mathrm{dm}^{-3}$ ) observed when $120 \mathrm{~kg} \mathrm{ha}^{-1}$ of $\mathrm{N}$ was applied, being the difference only 4.5 and 4.4 $\mathrm{mg} \mathrm{dm} \mathrm{dm}^{-3}$ of $\mathrm{K}$. However, when using the organic fertilizer, this difference increases to 19.1 and 18.4 $\mathrm{mg} \mathrm{dm}^{-3}$. It is important to obsrve that the $\mathrm{K}_{2} \mathrm{O}$ $\left(150 \mathrm{~kg} \mathrm{ha}^{-1}\right)$ was used as a corrective method of soil fertilization.

For the calcium concentration $(\mathrm{Ca})$, it is verified that within the levels of organic fertilizer studied, the doses of $\mathrm{N}$ tested presented better results for the Ca contents in the presence of the organic fertilizer. Without the organic fertilizer, the data was not adjustable to the tested regression models. When organic fertilizer was added, it was observed an adjustment to the quadratic model for the increase of Ca contents, according to $\mathrm{N}$ levels in both cycles.

It was estimated by regression equations that the highest Ca contents were 4.44 and 4.46 $\mathrm{cmolc} \mathrm{dm}^{-3}$ at the rates of 110.8 and $106.5 \mathrm{~kg} \mathrm{ha}^{-1}$ of $\mathrm{N}$ in the first and second cycle, respectively. Thus, when $\mathrm{N}$ and organic fertilizer are applied together, the concentration of $\mathrm{Ca}$ in the soil increases until a certain point.

Based on the initial soil Ca content before 
the application of the treatments $(4.17 \mathrm{cmolc}$ $\mathrm{dm}^{-3}$, Table 2) and comparing with the average content in the two cycles, it was verified an increase of $6.7 \%$. This content can be considered low, since the Ca content in the organic fertilizer was considerable (134.0 $\mathrm{kg} \mathrm{ha}^{-1}$, Table 3).

Magnesium (Mg) levels in the soil were affected in the same manner as the Ca contents by the $N$ doses and organic fertilizer (Table 4). However, it was observed in both cycles that, for the effect of $\mathrm{N}$ doses, the average levels of $\mathrm{Mg}$ present in the soil were statistically similar by the $F$ test. It was observed an adjustement only for the $\mathrm{Mg}$ levels referring to the $\mathrm{N}$ doses with the use of the organic fertilizer, with values of 1.56 and $1.57 \mathrm{cmolc} \mathrm{dm}^{-3}$ of $\mathrm{Mg}$, for the first and second cycle, respectively, when the higher dose of $\mathrm{N}$ was applied (120 kg ha-1).

Taking into consideration the content of $\mathrm{Mg}$ in the soil before the experiment installation (1.05 $\mathrm{cmol}_{\mathrm{c}} \mathrm{dm}^{-3}$, Table 2) and the average obtained between the two cycles, a $48.6 \%$ of increase was observed, due do the use of organic fertilizer. With its introduction, it is estimated that the content of approximately $65.0 \mathrm{~kg} \mathrm{ha}^{-1}$ of $\mathrm{Mg}$ (Table 3) was added to the soil.

Results of other researches show a significant contribution in the use of organic fertilizer to increase $\mathrm{Ca}$ and $\mathrm{Mg}$ contents in the soil. According to Silva et al. (2016), evaluating the use of organic fertilizer and $\mathrm{N}$ doses in the chemical characteristics of the soil cultivated with vines, when organic fertilizer was added, it was observed the $\mathrm{Ca}$ and $\mathrm{Mg}$ contents of the organic source of 301.5 and $103.5 \mathrm{~kg} \mathrm{ha}^{-1}$, respectively, values higher than those observed in the present study $\left(134.0\right.$ and $\left.65.0 \mathrm{~kg} \mathrm{ha}^{-1}\right)$. However, the nutritional composition of manure may vary according to the animal and to the diet in which animals are submitted, since in the previously mentioned research, the goat manure was used as organic fertilizer.

For the sodium $(\mathrm{Na})$ concentration it could be observed that, within the studied levels of organic fertilization, the $\mathrm{N}$ doses resulted in a higher sodium content in the presence of the organic fertilizer. However, according to the data for the tratments without the organic fertilization within the $\mathrm{N}$ levels, no statistical diferences were observed, according to the F test. Howerver, when the organic fertilizer was used, a quadratic behavior was observed, increasing the $\mathrm{Na}$ contentes according to the $\mathrm{N}$ levels, fot both evaluated cycles. This increase can be explained due to the introduction of the organic fertilizer, because considering the $\mathrm{Na}$ content, it was estimated an addition of $37.0 \mathrm{~kg} \mathrm{ha}^{-1}$ to the soil (Table 3).

For the highest $\mathrm{N}$ dose $\left(120 \mathrm{~kg} \mathrm{ha}^{-1}\right)$ applied, with the use of organic fertilizer, it was estimated, with the aid of regression equations, contents of 54.76 and $54.99 \mathrm{mg} \mathrm{dm}^{3}$ of $\mathrm{Na}$ in the first and second cycles, respectively (Table 5). Comparing the initial soil content $(49.0 \mathrm{mg} \mathrm{dm} 3$, Table 2) and adopting the average observed in the two cycles, it was observed an increase of approximately $12 \%$ of $\mathrm{Na}$.

The average concentration of the micronutrients ( $\mathrm{Fe}, \mathrm{Mn}$ and $\mathrm{Zn}$ ) after the vine cultivation in both cycles indicate that within the levels of organic fertilizer studied, the $\mathrm{N}$ rates promoted a higher concentration of $\mathrm{Fe}, \mathrm{Mn}$ and $\mathrm{Zn}$ in the presence of the organic fertilizer.

For the N levels studied within the organic fertilizer levels, it is observed that the average Fe, $\mathrm{Mn}$ and $\mathrm{Zn}$ contents were adjusted to the linear regression model in both cycles, indicating that both in the presence and in the absence of the organic fertilizer, the average concentration of $\mathrm{N}$ in the soil increased proportionally to the increase of the $\mathrm{N}$ doses.

On the other hand, the average levels of $\mathrm{Fe}$ in the first cycle, without the use of the organic fertilizer, were considered similar by the $\mathrm{F}$ test. For the second cycle, at $120 \mathrm{~kg} \mathrm{ha}^{-1}$ of $\mathrm{N}$, the estimated value was $12.39 \mathrm{mg} \mathrm{dm}^{3}$. Comparing this value to the content of 12.57 $\mathrm{mg} \mathrm{dm}{ }^{3}$ (Table 2) present in the soil before the treatments, a decrease of Fe content $10.18 \mathrm{mg}$ $\mathrm{dm} 3$ ) was observed. This can be explained by the absorption by the vine root system.

For the interaction of $\mathrm{N}$ with the organic fertilizer, the highest $N$ dose $\left(120 \mathrm{~kg} \mathrm{ha}^{-1}\right)$ was estimated at 14.32 and $14.41 \mathrm{mg} \mathrm{dm}{ }^{3}$ of $\mathrm{Fe}$ in the first and second cycle, respectively. In the two cycles, an increase of $14 \%$ was observed when compared to the initial soil content (12.57 $\mathrm{mg} \mathrm{dm}^{3}$, Table 2). It should be noticed that 
the organic fertilizer provided the increase of approximately $2.1 \mathrm{~kg} \mathrm{ha}^{-1}$ of Fe (Table 3).

The $\mathrm{Mn}$ and $\mathrm{Zn}$ contents at the $\mathrm{N}$ doses of the organic fertilizer were estimated at 31.05 and $31.17 \mathrm{mg} \mathrm{dm}^{3}$ for the $\mathrm{Mn}$, and from 3.86 and $3.97 \mathrm{mg} \mathrm{dm}^{3}$ for the $\mathrm{Zn}$. In the use of $\mathrm{N}$ and organic fertilizer, the estimated values were 48.24 and $48.33 \mathrm{mg} \mathrm{dm}^{3}$ for $\mathrm{Mn}$ and 5.90 and $5.99 \mathrm{mg}$ $\mathrm{dm}^{3}$ for $\mathrm{Zn}$, corresponding to the first and second cycle, respectively.

Table 5. Split of the total concentration of sodium ( $\mathrm{Na}$ ), iron (Fe), zinc (Zn) and manganese (Mn) in the soil cultivated with grapevine, under the influence of nitrogen fertilization, with and without organic fertilizer, in two crop cycles. Mossoró-RN, Brazil, 2017.

\begin{tabular}{|c|c|c|c|c|c|c|c|c|}
\hline \multirow{2}{*}{ Variable } & \multirow{2}{*}{ OF } & \multicolumn{5}{|c|}{ Nitrogen doses $\left(\mathrm{kg} \mathrm{ha}^{-1}\right)$} & \multirow{2}{*}{ Equation } & \multirow{2}{*}{$\mathrm{R}^{2}$} \\
\hline & & 0 & 30 & 60 & 90 & 120 & & \\
\hline \multicolumn{9}{|c|}{$1^{\text {st }}$ cycle } \\
\hline \multirow{2}{*}{$\mathrm{Na}$} & Without & $50.39 b$ & $50.42 b$ & $50.44 b$ & $50.40 \mathrm{~b}$ & $50.43 b$ & $\bar{y}=50.42 \mathrm{mg} \mathrm{dm}^{-3}$ & -1 \\
\hline & With & $52.33 a$ & $53.28 a$ & $53.84 a$ & $54.15 a$ & $54.67 a$ & $y=52.5413+0.0185 x$ & $0.96^{* *}$ \\
\hline \multirow{2}{*}{$\mathrm{Fe}$} & Without & $12.30 b$ & $12.23 b$ & $12.23 b$ & $12.29 \mathrm{~b}$ & $12.30 \mathrm{~b}$ & $\bar{y}=12.27 \mathrm{mg} \mathrm{dm}^{-3}$ & -1 \\
\hline & With & $12.42 a$ & $12.61 a$ & $13.32 a$ & $13.90 a$ & $14.30 a$ & $y=12.3030+0.0168 x$ & $0.98^{* *}$ \\
\hline \multirow{2}{*}{$M n$} & Without & $29.98 b$ & $30.09 b$ & $30.31 b$ & $30.88 b$ & $31.06 \mathrm{~b}$ & $y=29.874+0.0098 x$ & $0.94^{* *}$ \\
\hline & With & $33.36 a$ & $38.33 a$ & $42.30 a$ & $46.20 a$ & $46.64 a$ & $y=34.48+0.1147 x$ & $0.95^{* *}$ \\
\hline \multirow{2}{*}{ Zn } & Without & $3.55 \mathrm{~b}$ & $3.65 b$ & $3.73 b$ & $3.74 b$ & $3.86 b$ & $y=3.560+0.0024 x$ & $0.95^{* *}$ \\
\hline & With & $4.00 a$ & $4.52 \mathrm{a}$ & $5.04 a$ & $5.47 a$ & $5.86 a$ & $y=4.0486+0.01548 x$ & $0.99 * *$ \\
\hline \multicolumn{9}{|c|}{$2^{\text {nd }}$ cycle } \\
\hline \multirow{2}{*}{$\mathrm{Na}$} & Without & $50.27 b$ & $50.36 b$ & $50.38 b$ & $50.35 b$ & $50.37 b$ & $\bar{y}=50.35 \mathrm{mg} \mathrm{dm}^{-3}$ & -1 \\
\hline & With & $52.62 a$ & $53.50 a$ & $53.97 a$ & $54.43 a$ & $54.92 a$ & $y=52.7856+0.0184 x$ & $0.98^{* *}$ \\
\hline \multirow{2}{*}{$\mathrm{Fe}$} & Without & $12.20 b$ & $12.31 \mathrm{~b}$ & $12.32 \mathrm{~b}$ & $12.37 \mathrm{~b}$ & $12.37 \mathrm{~b}$ & $y=12.2407+0.00133 x$ & $0.84^{* *}$ \\
\hline & With & $12.50 a$ & $12.70 a$ & $13.42 a$ & $14.00 a$ & $14.38 a$ & $y=12.393+0.0168 x$ & $0.98^{* *}$ \\
\hline \multirow{2}{*}{$M n$} & Without & $29.91 b$ & $30.18 b$ & $30.39 b$ & $30.97 b$ & $31.15 b$ & $y=29.868+0.0109 x$ & $0.97^{* *}$ \\
\hline & With & $33.45 a$ & $38.42 a$ & $42.38 a$ & $46.29 a$ & $46.72 a$ & $y=34.570+0.1147 x$ & $0.95^{* *}$ \\
\hline \multirow{2}{*}{ Zn } & Without & $3.46 \mathrm{~b}$ & $3.73 b$ & $3.81 \mathrm{~b}$ & $3.82 b$ & $3.94 \mathrm{~b}$ & $y=3.5480+0.0035 x$ & $0.86^{* *}$ \\
\hline & With & $4.09 a$ & $4.61 \mathrm{a}$ & $5.13 a$ & $5.55 a$ & $5.94 a$ & $y=4.1386+0.0155 x$ & $0.99 * *$ \\
\hline
\end{tabular}

Considering thee initial soil content of $29.75 \mathrm{mg} \mathrm{dm}^{3}$ of $\mathrm{Mn}$ and $4.0 \mathrm{mg} \mathrm{dm}^{3}$ of $\mathrm{Zn}$ (Table 2) and adopting the average of the two cycles, it was verified that there was an increase of 1.36 $\mathrm{mg} \mathrm{dm} 3$ of $\mathrm{Mn}$, and a decrease of $0.09 \mathrm{mg} \mathrm{dm}^{3}$ for $\mathrm{Zn}$, regarding the effect of $\mathrm{N}$ doses without the use of the organic fertilizer. For the interaction of $\mathrm{N}$ and organic fertilizer, an increase of 18.53 and $1.94 \mathrm{mg} \mathrm{dm}^{3}$ of $\mathrm{Mn}$ and $\mathrm{Zn}$, corresponding to an increase of 62.3 and $48.5 \%$, respectively, was observed when comapred to the initial content. These results can be explained by the nutrient content provided by the organic fertilizer, since it was estimated na addition of 3.33 and $2.18 \mathrm{~kg}$ $\mathrm{ha}^{-1}$ of $\mathrm{Mn}$ and $\mathrm{Zn}$ (Table 3 ) to the soil.

Silva et al. (2016) observed that with the use of organic fertilization (goat manure), $\mathrm{Mn}$ levels increased $35 \%$ and $41 \%$ in the layers 0.0 20.0 and $20.0-40.0 \mathrm{~cm}$, respectively. These results were attributed to the content of $4.7 \mathrm{~kg} \mathrm{ha}^{-1}$ of $\mathrm{Mn}$ present in the organic fertilizer added to the soil. This same effect of the application of compost and other organic wastes was also described in the studies carried out by Bustamente et al. (2011) and Clemente et al. (2012).

The probable explanation for the micronutrient contents found in the absence of the organic fertilizer, follow the same reasoning used for the phosphorus. According to Malavolta (1979), the availability of $\mathrm{Fe}, \mathrm{Mn}$ and $\mathrm{Zn}$ are proportional to the decline in soil $\mathrm{pH}$. The $\mathrm{pH}$ value before the experiment installation was 7.95 (Table 2) and with increasing $\mathrm{N}$ doses, it was observed a linear decrease of soil $\mathrm{pH}$, leading to better conditions for the nutrients availability (Table 6).

According to the exposed, the $\mathrm{pH}$ soil variable was used to explain the availability of some previously discussed nutrients ( $\mathrm{P}, \mathrm{Fe}, \mathrm{Mn}$ and $\mathrm{Zn}$ ). Thus, it can be observed that $\mathrm{N}$ doses and their interaction with organic fertilizer were adjusted to the linear regression model in both evaluated cycles.

Using the regression equations, it was 
estimated at the dose of $120 \mathrm{~kg} \mathrm{ha}^{-1}$ of $\mathrm{N}, \mathrm{pH}$ values of 7.40 and 7.17 when only $N$ was used. For interaction with organic fertilizer the estimated values were of 7.52 and 7.44, corresponding to the first and second cycle, respectively. Based on the average value obtained by the sum of the two cycles and a correlation with the initial $\mathrm{pH}$ value (7.95 Table 2), it was observed a decrease of approximately 0.7 points when only $\mathrm{N}$ was used, while for interaction with organic fertilizer, this reduction was approximately 0.47 points.

Table 6. $\mathrm{pH}$, electric condutivity (EC), organic matter (OM) and sum of bases (SB) of soil cultivated with vine with $N$ fertilization and with ou without the use of organic fertilization, in two crop cycles. Mossoró-RN, Brazil, 2017.

\begin{tabular}{|c|c|c|c|c|c|c|c|c|}
\hline \multirow{2}{*}{ Variable } & \multirow{2}{*}{ OF } & \multicolumn{5}{|c|}{ Nitrogen doses $\left(\mathrm{kg} \mathrm{ha}^{-1}\right)$} & \multirow{2}{*}{ Equation } & \multirow{2}{*}{$R^{2}$} \\
\hline & & 0 & 30 & 60 & 90 & 120 & & \\
\hline \multicolumn{9}{|c|}{$1^{\text {st }}$ Cycle } \\
\hline \multirow{2}{*}{$\mathrm{pH}$} & Without & $7.90 a$ & $7.82 \mathrm{a}$ & $7.68 a$ & $7.58 a$ & $7.39 \mathrm{~b}$ & $y=7.930-0.0044 x$ & $0.98^{* *}$ \\
\hline & With & $7.86 b$ & $7.73 b$ & $7.68 a$ & $7.58 a$ & $7.54 a$ & $y=7.836-0.0026 x$ & $0.97^{* *}$ \\
\hline \multirow{2}{*}{ EC } & Without & $79.65 b$ & $79.83 b$ & $80.75 b$ & $81.65 b$ & $81.47 b$ & $y=79.580+0.0181 x$ & $0.89 * *$ \\
\hline & With & $82.62 a$ & $84.78 a$ & $85.82 a$ & $87.72 a$ & $88.33 a$ & $y=82.980+0.0479 x$ & $0.97^{* *}$ \\
\hline \multirow{2}{*}{$O M$} & Without & $3.75 b$ & $3.72 b$ & $3.68 b$ & $3.67 \mathrm{~b}$ & $3.61 \mathrm{~b}$ & $y=3.753-0.0011 x$ & $0.95^{* *}$ \\
\hline & With & $13.41 \mathrm{a}$ & $11.62 a$ & $10.88 a$ & $10.33 a$ & $10.11 \mathrm{a}$ & $y=13.324-0.058 x+2.6 e^{-4} x^{2}$ & $0.99 * *$ \\
\hline \multirow{2}{*}{ SB } & Without & $5.59 \mathrm{~b}$ & $5.74 b$ & $5.73 b$ & $5.68 \mathrm{~b}$ & $5.73 b$ & $\square=5.69 \mathrm{cmol}_{\mathrm{c}} \mathrm{dm}^{-3}$ & -2 \\
\hline & With & $5.83 a$ & $6.14 a$ & $6.33 a$ & $6.48 a$ & $6.60 a$ & $y=5.90+0.0063 x$ & $0.96^{* *}$ \\
\hline \multicolumn{9}{|c|}{$2^{\text {nd }}$ Cycle } \\
\hline \multirow{2}{*}{$\mathrm{pH}$} & Without & $7.86 a$ & $7.61 \mathrm{a}$ & $7.47 b$ & $7.37 b$ & $7.17 b$ & $y=7.822-0.0054 x$ & $0.98^{* *}$ \\
\hline & With & $7.71 b$ & $7.62 a$ & $7.55 a$ & $7.49 a$ & $7.46 a$ & $y=7.696-0.0021 x$ & $0.97^{* *}$ \\
\hline \multirow{2}{*}{ CE } & Without & $80.55 b$ & $80.73 b$ & $81.65 b$ & $82.55 b$ & $82.36 b$ & $y=80.480+0.0181 x$ & $0.89^{*}$ \\
\hline & With & $83.51 \mathrm{a}$ & $85.68 a$ & $86.71 \mathrm{a}$ & $88.61 \mathrm{a}$ & $89.23 a$ & $y=83.880+0.0479 x$ & $0.97^{* *}$ \\
\hline \multirow{2}{*}{ MO } & Without & $3.71 \mathrm{~b}$ & $3.64 b$ & $3.54 \mathrm{~b}$ & $3.60 \mathrm{~b}$ & $3.54 b$ & $\square=3.60 \mathrm{~g} \mathrm{~kg}^{-1}$ & -1 \\
\hline & With & $15.51 a$ & $13.58 a$ & $12.62 a$ & $12.28 a$ & $12.24 a$ & $y=15.445-0.0679 x+3.4 e^{-4} x^{2}$ & $0.99 * *$ \\
\hline \multirow{2}{*}{ SB } & Without & $5.50 \mathrm{~b}$ & $5.63 b$ & $5.67 \mathrm{~b}$ & $5.63 b$ & $5.63 b$ & $\square=5.61 \mathrm{cmol}_{\mathrm{c}} \mathrm{dm}^{-3}$ & -2 \\
\hline & With & $5.89 a$ & $6.32 a$ & $6.41 \mathrm{a}$ & $6.46 a$ & $6.63 a$ & $y=5.941+0.0107 x-4.5 e^{-5} x^{2}$ & $0.93^{* *}$ \\
\hline
\end{tabular}

According to Tasca et al. (2011), after the soil application, urea is hydrolyzed by the enzyme urease, resulting in ammonium formation. During this process, an increase of $\mathrm{pH}$ was initially observed, mainly around the fertilizer granules due to the consumption of the $\mathrm{H}^{+}$ions. However, after the ammonium nitrification, the $\mathrm{pH}$ decreases to values lower than the original content (ROCHETTE et al., 2009). Thus, each urea molecule produces, at the end of the ammonium nitrification process, a positive balance of two $\mathrm{H}^{+}$. Rosado et al. (2014), testing doses and sources of $\mathrm{N}$ applied to the soil, observed similar behavior, also attributing the results to the effect of the hydrolysis of urea in the soil, which produce $\mathrm{H}^{+}$ and contributed to the decrease of soil $\mathrm{pH}$, which are in accordance to the results obtained in the present study.

For the electrical condutivity (EC), it was observed that data was adjusted to the linear regression model, for both cycles (Tabela 6). It is important to observe that the mean values for the effect of $\mathrm{N}$ doses in the absence of organic fertilization are similar to the original value of the EC $\left(80,0 \mu \mathrm{S} \mathrm{m}^{-1}\right.$, Table 2).

Based on the derivative of the regression equations, for the $\mathrm{N}$ doses in the absence of the organic fertilizer, it was observed, using 120 $\mathrm{kg} \mathrm{ha}^{-1}$ of $\mathrm{N}$, the estimated values of 81.75 and $82.65 \mu \mathrm{S} \mathrm{m} \mathrm{m}^{-1}$. For the interaction of $\mathrm{N}$ with the organic fertilizer, the estimated values were 88.75 and $89.63 \mu \mathrm{S} \mathrm{m} \mathrm{m}^{-1}$ in the first and second cycles, respectively. Thus, using the average values obtained in each cycle, it was observed that an increase of $2.75 \%$ was accomplished for the $\mathrm{N}$ doses and approximately $11.5 \%$ for the interaction of $\mathrm{N}$ and organic fertilizer.

This fact was observed when $\mathrm{N}$ and organic fertilizer are used together and can be explained by the contribution of salts, mainly $\mathrm{Na}$ and $\mathrm{K}$ present in the organic fertilizer (Table 3). When the $N$ doses were absent from the organic fertilizer, a small increase occurred when compared to the original value, which could be 
the effect of the corrective fertilizer used in the soil, where the use of $\mathrm{KCl}$ (potassium chloride) may have provided this alteration. Thus, these levels would not be capable of causing damage to the vine development. Silva et al. (2016) observed similar results, observing that the use of goat manure resulted in an increase of soil EC, but without causing problems for the vine. However, in a study by Jiménez Becker et al. (2010) the authors observed that the application of organic fertilization increased the soil EC to such a high level that soil use would be restricted only to salt tolerant plants.

For the soil organic matter (OM) contents, within the studied levels of organic fertilizer, it can be verified in the two cycles that the $\mathrm{N}$ doses promoted better results when they were associated with the organic fertilizer. Analyzing the OM levels within the $\mathrm{N}$ levels studied, it is observed that, without the organic fertilizer, the first cycle data were adjusted to the linear regression model, estimating for the highest $\mathrm{N}$ dose the content of $3.62 \mathrm{~g} \mathrm{~kg}^{-1}$. For the first cycle, the data were considered with no statistic diferences, according to the $F$ test.

For the combined effect of $\mathrm{N}$ doses and organic fertiliztion, in both cycles, quadratic equations were adjusted, with contents of 10.1 and $12.0 \mathrm{~g} \mathrm{~kg}^{-1}$, estimated at the doses of 111.5 and $99.8 \mathrm{~kg} \mathrm{ha}^{-1}$ of $\mathrm{N}$. Considering the initial content of $4.07 \mathrm{~g} \mathrm{~kg}^{-1}$ present in the soil (Table 2 ), it is observed that decrease with the use of $\mathrm{N}$ with no organic fertilization. However, when organic fertilizer was associated with the $\mathrm{N}$ doses, an increase about $172 \%$ in soil OM content was verified, according to the average maximum values of each cycle.

Increases in soil OM due to the application of organic residues were also described by other authors (CLEMENTE et al., 2012; SILVA et al., 2014a). In a study by Silva et al. (2016) evaluating the influence of organic fertilizer and $\mathrm{N}$ rates on the chemical characteristics of soil cultivated with vines, it was observed that when organic fertilizer was added, the levels of soil OM increased from 6.87 to $17.09 \mathrm{~g} \mathrm{~kg}^{-1}$. Even so, the authors pointed out that this value is still considered low, suggesting the ideal for grapevines a value above $20 \mathrm{~g} \mathrm{~kg}^{-1}$. For the soil sum of bases (SB), within the studied levels of organic fertilizer, it was verified in the two cycles that the $\mathrm{N}$ doses promoted better results when associated with the organic fertilizer. On the other hand, for SB values within $\mathrm{N}$ levels, it is observed that in the absence of organic fertilization the data did not fit any regression model, in both cycles. For the combined effect of the $\mathrm{N}$ and organic fertilizer doses, the data of the first cycle were adjusted to the linear regression model, estimating for the highest $N$ dose a content of $6.65 \mathrm{cmolc} \mathrm{dm}^{-3}$ and for the second cycle an adjustment to the quadratic model was carried out, with a value of $6.57 \mathrm{cmolc} \mathrm{dm}^{-3}$, estimated with $118.9 \mathrm{~kg} \mathrm{ha}^{-1}$ of $\mathrm{N}$.

As can be seen, a superiority of the organic fertilizer and $\mathrm{N}$ combination occurred, demonstrating the possibility of establishing more viable fertilization alternatives for soils in the semiarid region, especially for sites where organic fertilizers, such as cattle manure, is available on the farm or at low cost. Thus, strategies of combined use between mineral fertilization and bovine manure can be an alternative in reducing costs and to improve the environmental quality of the cultivated areas.

\section{Acknowledgments}

To The Federal Rural University of the Semi-arid Region for supporting the research.

\section{Conclusions}

In the presence of nitrogen, the organic fertilizer resulted in an increase in the macro and micronutrient contents, in the organic matter and in the sum of bases, favoring improvements in soil fertility.

Nitrogen doses in with no use of organic fertilization were responsible for reducing $\mathrm{pH}$ levels, leadig to a greater nutrients availability.

\section{References}

BASSOI, L.H., DANTAS, B.F., LIMA FILHO, J.M.P., LIMA, M.A.C., LEÃO, P.C.S., SILVA, D.J., MAIA, J.L.T., SOUZA, C.R., SILVA, J.A.M., RAMOS, M.M. 2007. Preliminary results of a longterm experiment about RDI and PRD irrigation strategies in wine grape in São Francisco Valley, Brazil. Acta Horticulturae. 754: 275-282.

BRUNETTO, G., CERETTA, C.A., KAMINSKI, J., MELO, G.M., GIROTTO. E., TRENTIN, E.E., LOURENZI, C.R., VIEIRA, R.C.B., GATIBONI, L.C. 2009. Produção 
e composição química da uva de videiras Cabernet Sauvignon submetidas à adubação nitrogenada. Ciência Rural. 39: 2035-2041.

BUSTAMANTE, M.A., SAID-PULLICINO, D., AGULLÓ, E., AUDREU, J., PAREDES, C. 2011. Application of winery and distillery waste composts to a Jumilla (SE Spain) vineyard: effects on the characteristics of a calcareous sandy-loam soil. Agriculture, Ecosystems \& Environment. 140: 80-87.

CARNEIRO, W.J.O., SILVA, C.A., MUNIZ, J.A., SAVIAN, T.V. 2013. Mineralização de nitrogênio em Latossolos adubados com resíduos orgânicos. Revista Brasileira de Ciência do Solo. 37: 71 5-725.

CLEMENTE, R., WALKER, D.J., PARDO, T., MARTÍNEZ-FERNÁNDEZ, D., BERNAL, M.P. 2012. The use of a halophytic plant species and organic amendments for the remediation of a trace elements-contaminated soil under semi-arid conditions. Journal of Hazardous Materials. 223: 63-71.

EMBRAPA. 2009. Manual de análises químicas de solos, plantas e fertilizantes. Embrapa Informação Tecnológica, Brasília, BR. 627 p.

GALVÃO, S.R.S., SALCEDO, I.H., OLIVEIRA, F.F. 2008. Acumulação de nutrientes em solos arenosos adubados com esterco bovino. Pesquisa Agropecuária Brasileira. 43: 99-105.

GIACOMINI, S.J., AITA, C., JANTALIA, C.P., URQUIAGA, S. 2009. Aproveitamento pelo milho do nitrogênio amoniacal de dejetos líquidos de suínos em plantio direto e preparo reduzido do solo. Pesquisa Agropecuária Brasileira. 44: 761768.

INSTITUTO AGRONÔMICO DE PERNAMBUCO. 2008. Recomendações de adubação para o Estado de Pernambuco. IPA, Recife, BR. 64 p.

JIMÉNEZ BECKER, S., EBRAHIMZADEH, A., PLAZA HERRADA, B.M., LAO, M.T. 2010. Characterization of compost based on crop residues: changes in some chemical and physical properties of the soil after applying the compost as organic amendment. Communications in Soil Science and Plant Analysis. 41: 696-708.

LORENSINI, F., CERETTA, C.A., BRUNETTO, G., CERINI, J.B., LOURENZI, C.R., CONTI, L., TIECHER, T.L., SCHAPANSKI, D.E. 2014. Disponibilidade de nitrogênio de fontes minerais e orgânicas aplicadas em um Argissolo cultivado com videira. Revista Ceres. 61: 241-247.

LORENSINI, F., CERETTA, C.A., LOURENZI, C.R., CONTI, L., TIECHER, T.L., TRENTIN, G., BRUNETTO, G. 2015. Nitrogen fertilization of Cabernet Sauvignon grapevines: yield, total nitrogen content in the leaves and must composition. Acta Scientiarum Agronomy. 37: 321-329.
MAEDA, S., BOGNOLA, I.A. 2012. Influência de calagem e adubação fosfatada no crescimento inicial de eucalipto e nos níveis críticos de $\mathrm{P}$. Pesquisa Florestal Brasileira. 32: 401-407.

MALAVOLTA, E. 1979. ABC da Adubação. Editora Agronomia Ceres, São Paulo, BR. 255 p.

MENEZES, R.S.C., SALCEDO, I.H. 2007. Mineralização de $\mathrm{N}$ após incorporação de adubos orgânicos em um Neossolo Regolítico cultivado com milho. Revista Brasileira de Engenharia Agrícola e Ambiental. 11:361-367.

POTRICH, D.C., MARCHETTI, M.E., POTRICH, D.C., ENSINAS, S.C., SERRA, A.P., SILVA, E.F., SOUZA, N.H. 2014. Decomposição de resíduos culturais de cana-de-açúcar submetidos a diferentes doses de nitrogênio. Semina: Ciências Agrárias. 35: 1751-1760.

RÊGO, L.G.S., MARTINS, C.M., SILVA, E.F., SILVA, J.J.A., LIMA, R.N.S. 2016. Pedogenesis and soil classification of an experimental farm in Mossoró, State of Rio Grande do Norte, Brazil. Revista Caatinga. 29: 1036-1042.

ROCHETTE, P., MACDONALD, J.D., ANGERS, D., CHANTINI, M.H., GASSER, M., BERTRAND, N. 2009. Banding urea increased ammonia volatilization in a dry acidic soil. Journal of Environmental Quality. 38: 1383-1390.

ROSADO, T.L., GONTIJO, I., ALMEIDA, M.S., ANDRADE, F.V. 2014. Fontes e doses de nitrogênio e alterações nos atributos químicos de um Latossolo cultivado com Capim-Mombaça. Revista Brasileira de Ciência do Solo. 38: 840-849.

SILVA, D.J., BASSOI, L.H., ROCHA, M.G., SILVA, A.O., DEON, M.D. 2016. Organic and nitrogen fertilization of soil under 'Syrah' grapevine: effects on soil chemical properties and nitrate concentration. Revista Brasileira de Ciência do Solo. 40: 1-11.

SILVA, D.J., SILVA, A.O., BASSOI, L.H., COSTA, B.R.S., TEIXEIRA, R., SOUZA, D.R.M. 2014a. Adubação orgânica e fertirrigação potássica em videira 'Syrah' no Semiárido. Irriga. 1: 168-178.

SILVA, V.B., SILVA, A.P., DIAS, B.O., ARAÚJO, J.L., SANTOS, D., FRANCO, R.P. 2014b. Decomposição e liberação de N, P e K de esterco Bovino e de cama de frango isolados ou misturados. Revista Brasileira de Ciência do Solo. 38: 1537-1546.

SOUTO, P.C., SOUTO, J.S., NASCIMENTO, J.A.M. 2013. Liberação de nutrientes de estercos em Luvissolo no semiárido paraibano. Revista Caatinga. 26: 69-78.

TASCA, F.A., ERNANI, P.R., ROGERI, D.A., GATIBONI, L.C., CASSOL, P.C. 2011 . Volatilização de amônia do solo após a aplicação de ureia convencional 
ou com inibidor de urease. Revista Brasileira de Ciência do Solo. 35: 493-502.

TEDESCO, M.J., GIANELLO, C., BISSANI, C.A., BOHNEN, H., VOLKWEISS, S.J. 1995. Análise de solo, plantas e outros materiais. UFRGS, Porto Alegre, BR. 174 p.

VERAS, M.S., RAMOS, M.L.G., OLIVEIRA, D.N.S., FIGUEIREDO, C.C., CARVALHO, A.M., PULROLNIK, K., SOUZA, K.W. 2016. Cover Crops and Nitrogen Fertilization Effects on Nitrogen Soil Fractions under Corn Cultivation in a No-Tillage System. Revista Brasileira de Ciência do Solo. 40: 1-12. 